\title{
Potentials Of Urban Agriculture In ReFLECTION OF \\ "The Thessaloniki Project - Red And Green"
}

\author{
Zsuzsanna Fáczányi \\ Institute of Architecture, \\ Ybl Miklós Faculty of Architecture, Szent István University, Budapest, Hungary \\ faczanyi.zsuzsa@ybl.szie.hu
}

\begin{abstract}
In spite of the fact the scene of food production is the rural territory; we are witnessing more and more unusual endeavours for farming in cities, additionally in megalopolises. There are numerous researches on the theme, and the new interest in the local cultivation of fruit and vegetable in cities is becoming an earnest factor in urban life in Western Europe, in the USA, and in the Developing World. At the Aristotle University of Thessaloniki, AUTh two professors of architecture managed a course for MSc students of architecture and horticulture, with the intend of designing forms of urban agriculture on a fallow area in Thessaloniki, and considering the crisis situation in Greek. With analysing the proposals of "The Thessaloniki project - Red and Green" parallel with various realized urban agriculture projects I emphasise the force and necessity of the generation of a community.
\end{abstract}

Keywords: Community agriculture, Self-provisioning, Rural and Urban, Sustainable city, Urban farming in Thessaloniki

\section{INTRODUCTION}

Urban Agriculture, thus the Paradigms "Producer Village" and "Consumer City"

Rural areas have the primary function of food production by agriculture and usually have a low population density. Therefore they are the hinterland of the urban entity, which they provide with food and raw material. An urban settlement is a dense multifunctional concentration of industry, trade, administration and culture, and can have an extremely large population, coevally a solid market for agriculture. Cities' green and open spaces are clearly outweighed by the built-up substance, there can be a keen land use competition with high land rents. Nonetheless, they are historical and present appearances of appreciable husbandry in the urban context, and while on one side correlated with increased poverty caused by vast economic crises or the World Wars; on the other side the social and individual human demand generates practices here, like the allotment's movement in Europe, or community gardening, which seems to be the reactions on the "crisis" to urban life. The practice of urban agriculture can gain an important role in the forming of an environmentally aware approach in the future, in regard to the depletion of natural resources influenced by the unsustainable extraction of raw material force this can help the field of food production with creativity as well. 
Intention of "The Thessaloniki Project - Red and Green"

Prof. Holm Kleinmann and Prof. Sarantis Zafeiropoulos at the School of Architecture (AUTh), Aristotle University Thessaloniki were the innovators of the project. With contrivance of the urban planning they search ways out of the economic, social and psychological disaster of Greece. Under their conception a course of 2.MaT STUDIO, Postgraduate Landscape Architecture - Architectural Design and Landscape was offered for MSc students of both of the disciplines of architecture and horticultural gardening. Eventually 4 groups, each of 22 students of both faculties were working on their proposals for one semester, in addition to a final jury of international experts, where I had the opportunity, to take part. The studio was working on the question, "...how much Urban Agriculture can contribute to an urban development in Thessaloniki, which opens the social, economic and ecological renewal of the city with innovative dimensions. The focus here is on the integration of agriculture into urban development and on its transformation from rural land use category as we know from the villages; into a multifunctional green infrastructure.” The „Red” approach has a special emphasis here that denotes the expectable community, evolving during the concept.[1]

\section{Goal of the Analysis}

It is exceptionally important to confront the future's professionals with the problems of urban agriculture, as there is an enormous social stratum of presently unemployed, motiveless people in Greece in this generation - that would have potential. The demanded role of the planner is interesting, because of the assignment to design the function, the possible actors and the economic base of this unaccustomed development parallel too. However in this aspect some questions are yet to be answered. Nevertheless, finding the beneficial target groups, over the financial base is the earnest of the sustainable future of the "Urban Green". In addition interesting questions were posed and in some cases were left unacknowledged about urban farming, like the aspect of property safety and the degree of publicity, the way and grade of interdigitation with the socially multifaceted surrounding. Consequently, with the help of the analyses of the project works, furthermore of acting urban agricultural forms, I intend to carry on the contexture and contribute to the ideas of the urban food production, also in Thessaloniki.

\section{ANALYSIS}

\subsection{Main Motives and Belonging Forms of Appearance of Urban Agriculture since the 1990s}

Motives and actors determine the way of farming, in the cities as well. Consequently, I emphasize these two factors at actualized examples of urban agriculture, to intensify the strongnesses and perhaps the weaknesses in the students' proposals. In this regard I grouped four categories of urban agriculture.

'KLEINMANN, H.,(2013) [1] 


\section{Motive 1.Poverty Caused by Economical Crisis}

Urban agriculture, as an economy of short-cut ways, the local cultivation of fruit and vegetables on fallow territories brought the solution for cities with enormous economic problems in food sovereignty - as for example the metamorphosis of the sustenance of Cuba, where the activity of food-production was taken over from the urban actors, however, with outstanding land use and productivity. The collapse of Cuba's main trade partner the Soviet Union, and then the US embargo in the period of 1989-92 lead to the interruption of food import, agricultural inputs and oil import to the island. Consequently, the extremely highly industrialized, monocultural agriculture based food-production and -transport of Cuba was dissolved. Food was exiguous, in consequence expensive and the so called "Revolution Verde" of subsistence farming in the cities evolved. The process had state support with relaxing laws on the sale of garden products, through technological and informational services and through the establishment of extensive state-run gardens. Organipónicos, located in areas unsuited for agriculture, using containers or raised beds and intensive gardens, in areas with high quality soils, drainage, and adequate water supply; so seeds that are planted directly into fertilized soil - are the primary way of cultivation. Popular gardens are easily accessible to the public and are cultivated mostly by communities on abandoned or vacant plots. Beside these state or privately owned suburban farms, enterprise and factory gardens, and state owned hydroponics enframe urban husbandry. The extent of urban farming in the city of Havana in 1997 was 15'092 ha, whereby the food-supply of the whole city was ensured. $[2,4,11]$

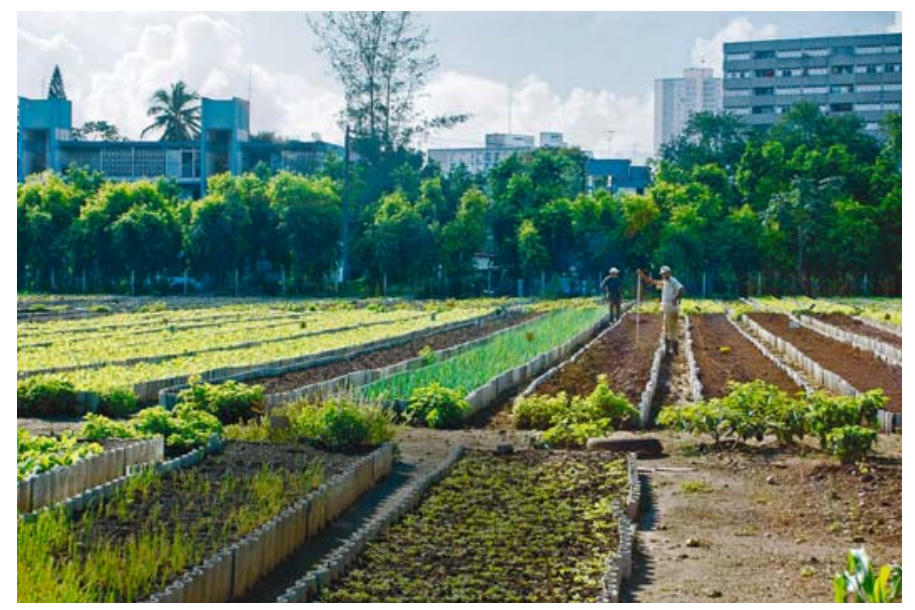

Figure 1. 'Organoponic' by Nelsón León Nicolau, IDRC Photo [3]

\section{Motive 2.Social and Individual Demand set up Community Gardens}

Urban Gardening movement focuses principally on social components and joint cultivation. Substance is rarely possible, not the yield, more the community, and the improvement of urban life quality, a responsible relation with the environment are important.[5] Here is the emphatic framing of the intention of the community of the "Prinzessinengärten" in Berlin: "In einem Bezirk mit hoher Verdichtung, wenig Grün und vielen sozialen Problemen können Kinder, Jugendliche und Erwachsene, Nachbarn, interessierte Laien, passionierte Gärtner und Freiluftenthusiasten - mit einem Wort jeder, der will - in dieser sozialen und ökologischen Landwirtschaft in der Stadt gemeinsam mit uns lernen, wie man lokal Lebensmittel herstellt 
und gemeinsam einen neuen Ort urbanen Lebens schafft..." [6] However, an interesting experience to the formation of community gardens in Budapest is the presence and the mediating work of the "Városi Kertek Egyesület", established with the intention, to accomplish community gardens in Budapest. Their basic idea is serving mostly building estates, where there are commonly no existing neighbourhood communities, and usually no common green area is to use. The association negotiates with the municipality, propounds project flow chart and discusses about vacant plots. Insofar successful, local government volition and investment offer the piece of ground, build fences, and purchase the material for raised beds at the future community's disposal. Hereinafter begins the organization of the community, and the founded collectivity comes to a decision about the fulfilment of the garden. Without the agency of the mediators there is no significant efficient force to self-determination.

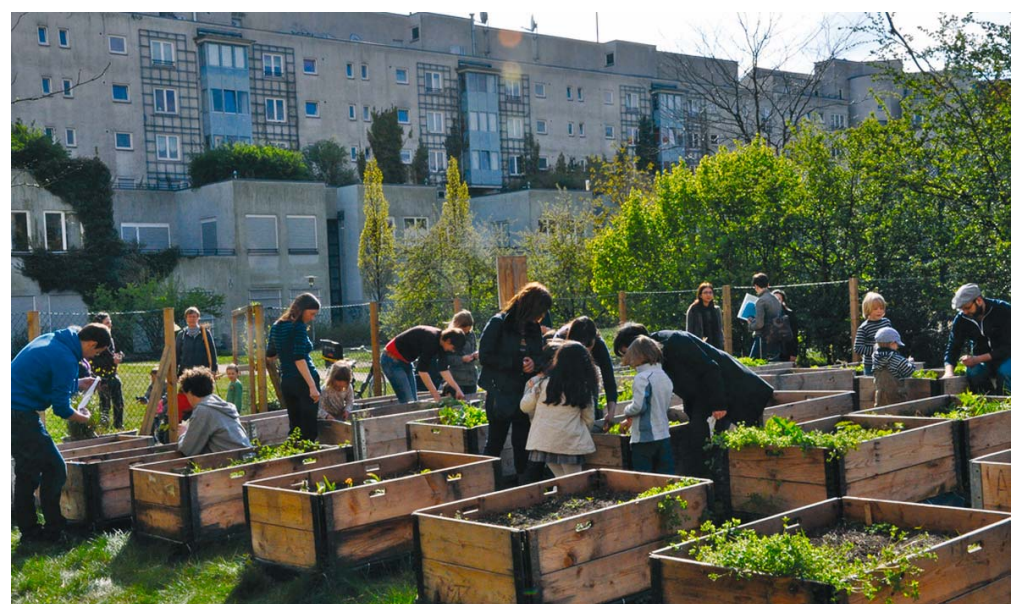

Figure 2. Prinzessinengärten by MarcoKlausen [6]

\section{Motive 3.Governemental or Company Forced Investments}

The Dutch design firm, van Bergen Kolpa Architecten, has plans to build a 4,000 acre park in the middle of Holland's most populous area, the Randstad, that includes Amsterdam, Rotterdam, The Hague and Utrecht. The firm plans to control the climate of the park strictly, allowing for what they call "new climate zones" such as moderate, Mediterranean and tropical areas that will produce foods unable to grow in the North Atlantic by using "old techniques such as warmth accumulating snake walls and more contemporary solutions as insulating water spray 'roofs' and floor heating on the basis of thermal warmth." Currently, according to van Bergen, the firm is working with the Dutch farmers' cooperative Oregional and the governments and residents of Rotterdam and Nijmegen cities toward the realization of the first phase of Park Supermarket.[7]

\footnotetext{
${ }^{2}$ In a district of high density, less green and a lot of social problems children, youth and adults, neighbours, intrestedlaity, obsessed gardeners and open-air-enthusiasts - shortly, everybody -, who want to learn with us mutually, in this social and ecological urban farm, how to produce local food and create a place of urban life...(own translation) Homepage Prinzessinegärten [6]

${ }^{3}$ Urban Garden Association (own translation)
} 


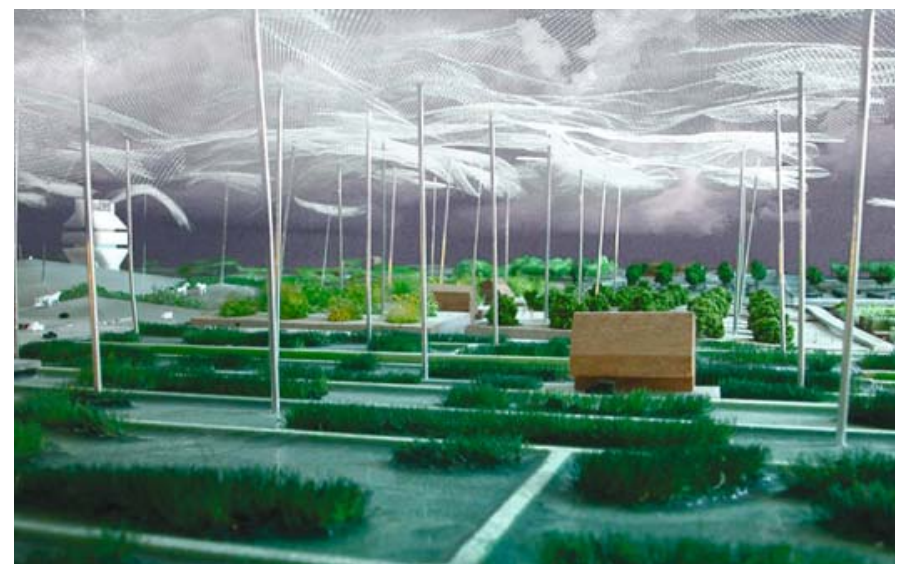

Figure 3. The Rice Department, Photo by Kolpa Architects [8]

Motive 4.Research

CEO of UrbanFarmers AG, a pioneering Spin-off from the University of Applied Sciences (ZHAW) in Wädenswil develop a research Projects UF Controller - a system to processcontrolling the Aquaponic Constructions in urban farming, that aims to bring sustainable urban agricultural practices into cities of the $21^{\text {th }}$ century. Based on the research, Europe's first commercial aquaponic rooftop farm will be realized in Basel, with the directive to reach outstanding output.[9]

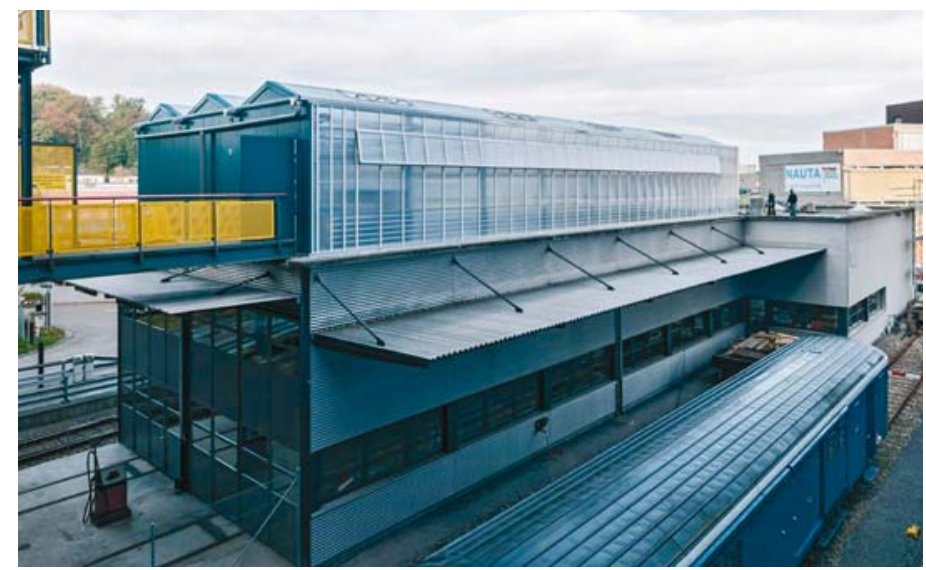

Figure 4. "LockDepot" rooftop farm, Dreispitz, Basel. [10]

\subsection{The Thessaloniki Project}

According to Prof. H. Kleinmann, ,The strength of green urban energies generated by the projects of "Urban Gardening" and "Urban Agriculture" can be noticed in the overall connection of climate optimization, cities nutrition and a decentralized local approach. [...] The green is the centre of new urban energies. It is the source and initial point for a social, economic and educational restart with impact to new forms of integration." ${ }^{\prime 4}[11]$

\footnotetext{
${ }^{4}$ KLeinmann, H.,(2013) [11]
} 


\subsubsection{Description of the problem}

\section{Thessaloniki}

The city of Thessaloniki is the second largest city of Greece. In Greek dimensions it is not an ancient settlement, because it was founded at the beginning of the Hellenistic time, at about 300 B.C., as it was seat of Alexander, The Great. The city was built up at the coast of Thessaloniki bay, along the roman road Via Egnatia that starts in Dyrrachium (now Durrës) and ends in the city of Byzantiu (later Constanople, now Istanbul).[12] The present structure of Thessaloniki resembles to a butterfly-shape; this corpus was crystallized in the Byzantine times, with the wall surrounded old town, then the city spread from the coast up to the hill built citadel, now prison (Eptapirgio). The former old town has three parts, inhabited by the Greek, the Turkish and the Jewish population. To the west, as one wing of the butterfly, the seaport was built, as the logistic-industrial centre of the city, with intermodal road junctions. As the other wing south-east of the old-town is a new residential area (Kalamaria), was built characteristically in the late modern fever of the second part of the $20^{\text {th }}$ century.

\section{Site of the Project}

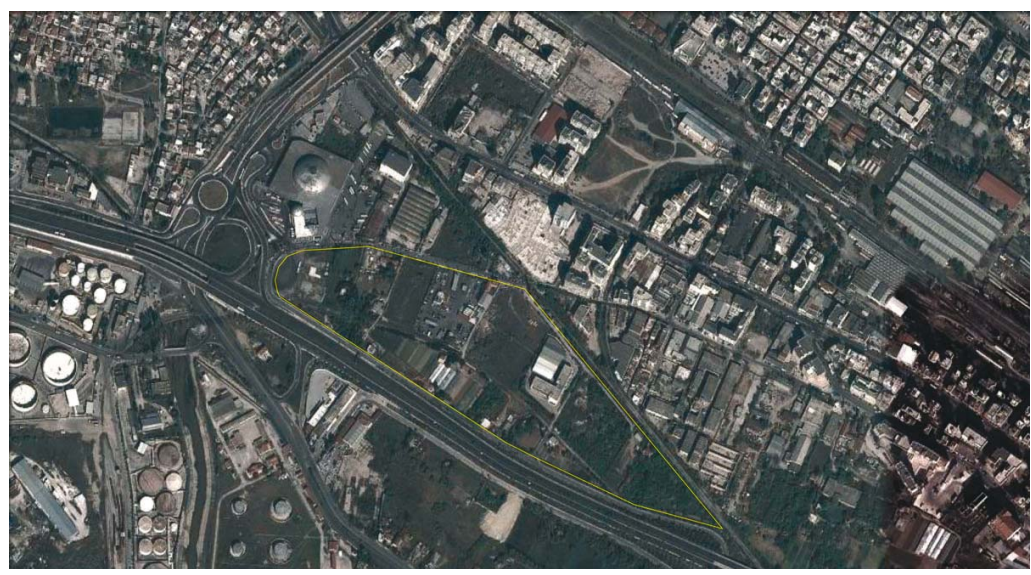

Figure 5. Thessaloniki on Google Maps [13]

Site of the design work is situated in the ecotone of the west wing. The lance-shaped territory presently is a huge fallow field, on the south-west long side, bordered by the main road A/D Path Thessaloniki, the recent tally of the Egnatia. The area is confined with the railway path on the north-east, beyond a socially damaged dwelling district. At the spear-head the speedway and the railway line have an overhead crossing, while at the west end a new dome shaped city bus station (Menemeni) was built in the $2000^{\text {th }}$. South-west to the scene an industrial area, Sindos adjoins. Contingently belonging to the field of the designed activity is the dense residential area Dendropotamos. Urban Agriculture "in the area of "Lachano-Kypoi" had an important history in the nutritional supply of the people of Thessaloniki in former times of extreme sufferings and hardships and it might become a new future in this current moment of crisis." ${ }^{5}[1]$

\footnotetext{
${ }^{5}$ KLeinmann, H., (2013) [1]
} 


\section{Conceptual Formulation}

In the first case the Focus of the country planning are the problems of the bordering, low quality, social dwelling area, with the intention to offer solutions for the economic crises in Greece. The north-eastern territory is characterised by migrated inhabitants, segregation and unemployment. Local solutions have to bring sustainable changes. The Program defined the following functions needed:

a) Permanent housing (ground min. 3.000 square meters);

b) Temporary housing (in different forms of variety);

c) Urban gardening, for private purposes;

d) Urban gardening with public accessibility;

e) Urban agriculture, land for cultivation (cooperatives etc.);

f) Market with green commodities, marketable items like vegetables, fruits, etc.; open space, covered space, storage also in winter time;

g) Open uses to invent by the students, private or public, also in form of buildings and lots.[1]

\subsubsection{Exposition of the Proposals}

\section{Agri Labor School ${ }^{6}$}

In the focus of the project is education, the Agri Labor School, in connection with the University of Thessaloniki, and the University Farmland, on the north-west of the Central Vegetable Market, farther on the Diavata Agricultural Holding, what is the main area of greenhouses. In their analyses of the area they diagnosed the crisis, poverty and a need for nutrition; however the citizens show a lack of knowledge in agriculture. Cultivatable land is available, beyond this one under review there are further abandoned plots in the city. The students presented a suggestion for an Open School about garden design, agriculture, harvesting, plants' care, food production, cooking, conservation, and thus supporting the primary product chain, with the collaboration of Greek companies occupied with agriculture and food production. The result on the „Green” side would be product „receipts”, innovation, new food research, agri-knowledge, with the impact of the University of Thessaloniki, Thessaloniki International Fair, Imathia Greenhouses, Sindos industrial cluster give value to local infrastructures. From the „Red” point of view collective knowledge, community spirit, solidarity, direct food production can be set out. Conceptually they divided the territory into two parts. On the northwest is the crystalline designed public thematic park of research and agricultural innovation is situated. Facing the bus station is a temporal, open canopy market, as well as buildings of seminars, exhibitions, a research centre, a library and a café. The agricultural land extends in the south-east as a social community environment, with possibilities for permanent and temporal housing and for social integration. The First function accommodates the population of the neighbourhood with a pattern of agricultural land use, and they have the possibility to practice it in the communal area. Beneficial proposal are to collect compost and take care of the waste-management.[14]

The design is of balanced quality, it presupposes an achievable grade of governmental motivation and investigation, due to the economic situation.

\footnotetext{
${ }^{6}$ Design group: Eleftheria Gavriilidou, Dionysia Dedousi, Eleni Oureilidou, Maria Ritou [14]
} 
The allocation of the market assumes the turnover from the bus station and the Dendropotamos residential area, however it's questionable, in addition far away from residential areas that are northern from the site. Public thematic gardens have an affluent urban character, whether the exposed demand for this kind of use is legitimate. Residents are reusing the containers, according the crisis situation and the target group of move-in people, although it is a doubtful construction for Mediterranean climate. The most significant modification I would suggest is the organization of the residential houses, insomuch the lack of just the "Red" content. Based on the experiences in Budapest, I would organize the new denizens in small common units, about 30 participants each, and would give them a land for cultivation on the pattern of community gardens. The members should have own parcels, but also a common one, further the existence of one central community building - a place for meetings or common meals is essential. Equal principles could be applied by the citizens of the neighbourhood too. Communities of these sizes can arrive at a decision; compose a sustainable unit, enabling the rooting of the inclusion of urban agriculture into the existing social context.

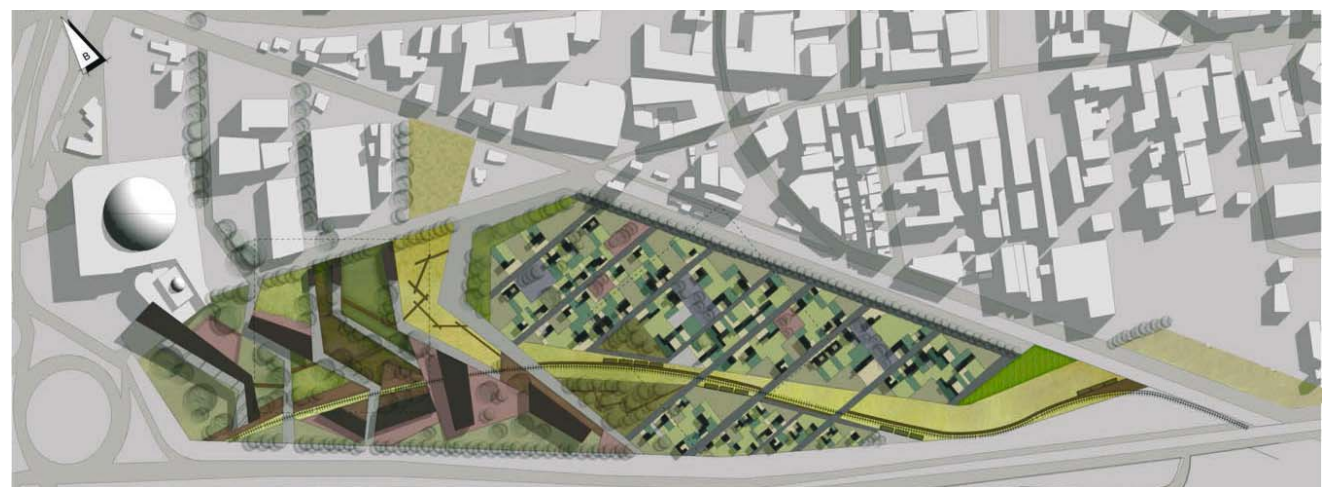

Figure 6. Masterplan, Agri Labor School [14]

\section{LANDSCAPE MEDIC(AID) ${ }^{7}$}

During the course of analyses of the site this group considers the pollution of the soil extremely significant, that was caused by the contaminated stream coming from Reffinaries northwards and the district Dendropotamos to decontaminate, they suggest a lengthwise, mesial zone of Phytoremediation, including the fore-and-aft main walking pass, besides warehouses and meeting squares. This results an echelonment of the area into three linear dimensioned belts, northern the housing zone, with the central market, and a territory of sport fields. In the south of the band of Phytoremediation is the zone of the research centre and the adherent glasshouses. The main entrance faces the central bus station with shops, and a stoa. The housing area bordering to the train line with lined private houses, girdled with private gardens, adjoining the public cultivated land, with warehouses, meeting places and a soup-kitchen. The form of housing is the reuse of containers, too - with idealized ground-plans characterising city life, probably unsuitable to agricultural lifestyle.[15]

Rainwater "harvesting” is commendable. The land-use of the public cultivation shows the contexture of eco-municipalities.

${ }_{7}^{7}$ Design group: Zoi Marmataki, Sofia Mastoropoulou, Anna Paraschou, Stefania Anna Piperidou [15] 
Moreover the personality needs private efforts to be proud of, hence this kind of common work doesn't generate the growth of communities[16], particularly not from „outside”, but it can offer possibility of employment. Private gardens would seem too large, also in contradiction with the neighbouring, troubled socio-economic housing environment. The strongness of the proposal is to dealing with the contamination, as it could be determinant on the yield of the cultivation. However, I don't feel quite exact about the determination of the locality of the pollution, as for example it would be consequent, to use raised beds with brought soil for private and public cultivation, too. The tool of phytoremediation also delays the earnings of urban agriculture. According to the above statements there is a lack of „red” community, and the intergrowth with the surrounding was not come into being yet.

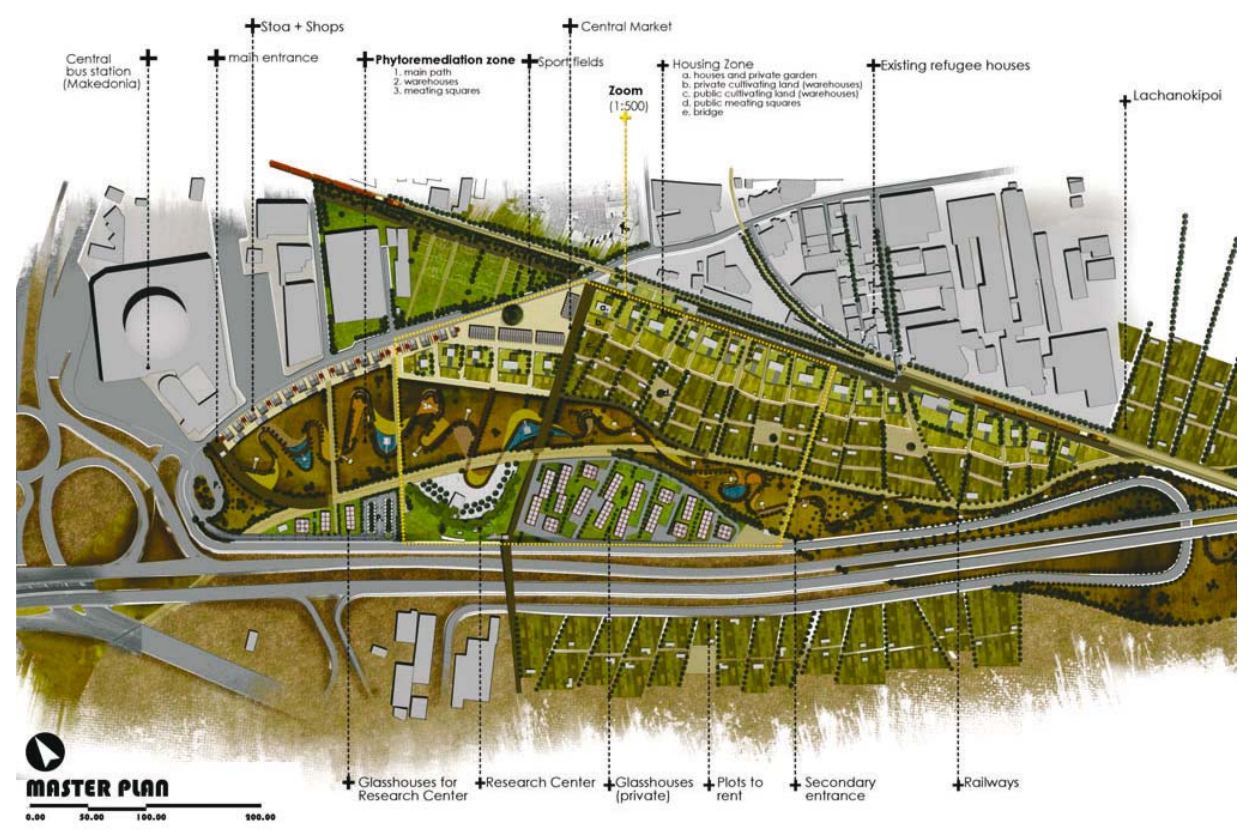

Figure 7. Masterplan, Landscape Medical (AID) [16]

\section{Agro(Polis) $)^{8}$}

Agropolis combines the Latin word ,ager” with the Greek word „polis”, and means a City of fields or an agricultural city. [Agropolisoskönyv] „The main aim of the project was to set the standard for urban agricultural design that enhances the urban experience and highlights the interrelationship of landscape, agriculture and the built environment." Agricultural content here is meant by allotments, orchards and hydro-, aqua- and aeroponics, in correlations with housing, energy management, recreation and commerce. The Main entrance of the area is at the bus station, ,a green wall, where citizens, tourists \& visitors of the park will plant fresh herbs creating themselves the entrance of the park" and it open up to a 2 ha territory of community orchards. This is a place for fruit production, also for leisure, education and meeting. Alongside the south-western speedway the area of Ponics Educational Park is disposed, what is a plot of exploration for researches of water-saving methods of cultivation.

\footnotetext{
${ }^{8}$ Design group: Menia Bassiakou, Renia Chatzigeorgiou, Eleni Georgiadou, Anna Mavropoulou [17]

${ }^{9}$ Final proposal of the group „AgroPolis”
} 
South of the motorway a suggestion for building an energy park was made, with educational purposes about energy crops, water management and composting. The housing area extends until the north-east border of the site, in front of the residental area beyond the railway pass. Location of the new housing units is organized around courtyards, with ambiguous appearance. The functions above enringe about 4-5 ha of the allotments; these are in the meaning of community gardens, where residents of the park and citizens of Thessaloniki can grow their own vegetables following the principles of organic agriculture. [17] The proposal has confidence in the future, but a conflict of the trendy architectural style of the villa-like feel and the "Red” dilemma in the crises coexists henceforward. The spread of orchards need expertise and the public use raises a question of safeguarding. Ponics Park, that is also this quality of housing requires more significant investigation; however, the economic situation is out of resources. Such high quality of living can stay a reservate in the problematical context. If these allotments were used like „Schrebergärten”s, individual demesnes, as in Switzerland or in Germany, the power of the community may be failing. It is a city of fields indeed, and can give opportunity for employment or subsistence farming.

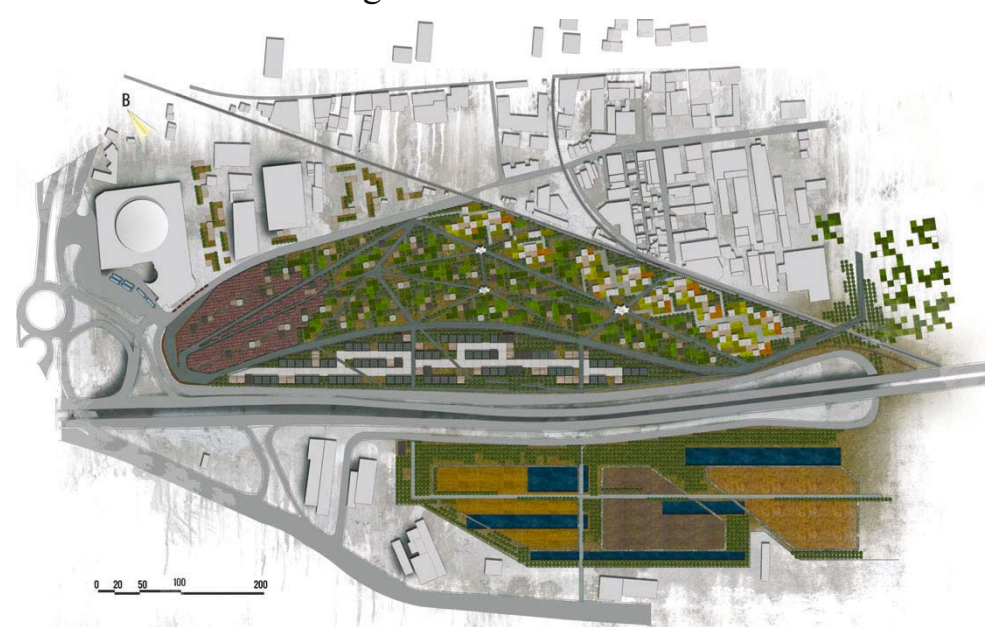

Figure 8. Masterplan Agro (Polis) [17]

\section{CELLS $^{10}$}

First intentions of this group were reintegration of empty spaces to the urban tissue, redefining of the land use, mild exploitation of the land, awaking of community, participation and education. „Cells” is an acronym, as long as „C" stands for cultivating community, „E” for education, both L"-s for leisure and labour, and lastly „S” for sustainability. In the planting strategy the students appoint categories of applied plants: trees bearing fruit, nuts and secondary products; seasonal vegetables in open fields, green houses and vertical systems; vines for grapes, wine and tsipouro; aloe plants in greenhouses for processed products and forest trees for microclimate improvement, making a friendly and healthy environment. Cultivation occurs in a dense, mostly industrialized manner, besides of open fields, application of vertical growth, green houses and hydroponics. Investor and employer attitude, nonetheless offers part time work for people with low or no income.[18]

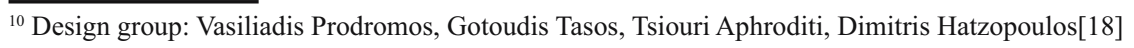


It is a deliberate proposal for local-grown food and using the forces of the site, like solarenergy and rainwater, but is step by the conceptual formulation. There is no use of potentials from „Red and Green”.

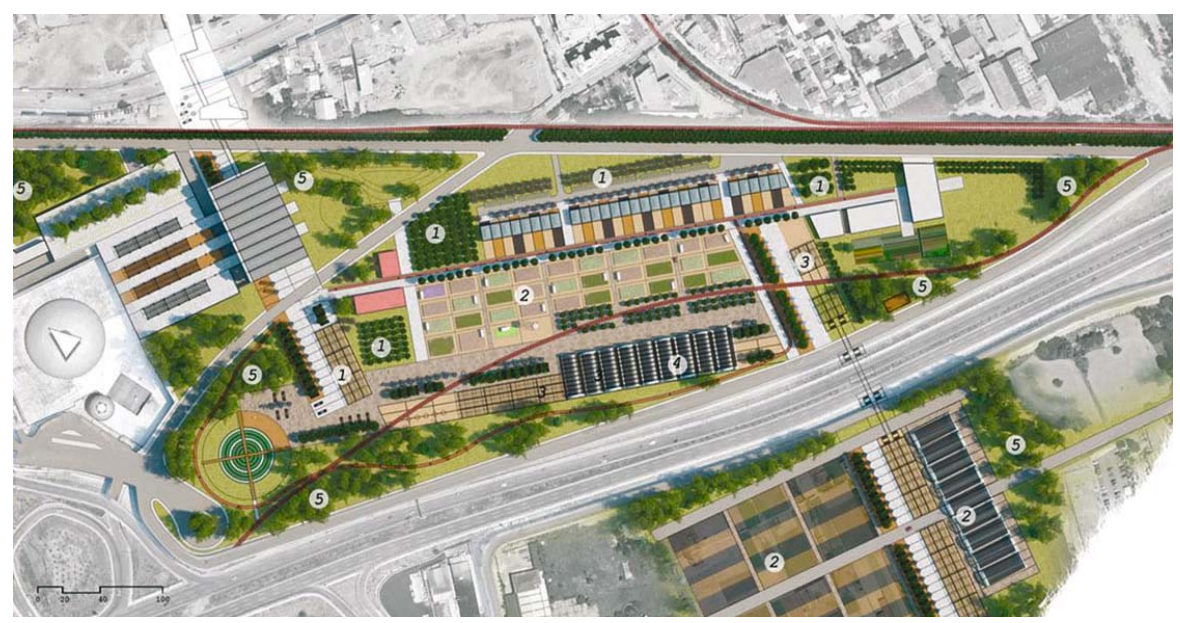

Figure 9. Masterplan, Cells [18]

\section{CONCLUSIONS}

The situation in Greece is, as Prof. Holm Kleinmann formulating “... as a whole, economically, socially and psychologically [...] a disaster. Full of despair, without hope, individuals and families have found themselves lost in a jungle. The belief in institutions, private and public, decreased towards zero." ${ }^{11}$ Sufficient force for sweeping changes is needed, but governmental interfering, or investments of enterprises seem not to be in the offing. The „Red and Green”, the potential of communities and the force of the nature, first as the sprout in „Lachanokipoi”, and then more and more islands emerging in the city - can be the power of recovery. For the sustainability of urban agriculture the rooting of the new inclusion into the neighbouring context is important, otherwise the intervention intensify social problems, like social disparities, isolation, and discrimination. The way of thinking about cities as the scene of "Urban Mining" is recommended, therethrough human, and environmental resources should be used. The student proposals had brought creative suggestions in the architectural and landscape design, elaborated from very different points of views. The projects included the use of solar energy, rainwater, urban compost, and also recycled materials (environmental resources). But after all in none of them was the "Mining" of the "Common", the trust in the collective intelligence, the "Red" element strong enough. I hypothesize a parallelism between the Hungarian and Greek society, in spite of the tradition of community initiative - this could be the subject of a sociological survey - that's why I cathect the role of mediation in the formation of communities.

The "Urban Garden Association" in Hungary [16], lean on the project management work of Rosta Gábor, had mediate in the process of the realization of six community gardens in Budapest and interacted between residents of the neighbouring building estates and the local government, with the result of initiation of working communities as the assumption of the sustainability of the project.

\footnotetext{
${ }^{11}$ KLeinmann, H., (2013) [1]
} 


\section{ACKNOWLEDGMENTS}

My participation in the work of the international final jury in Thessaloniki in the academic year 2013/2014 was made possible by the Erasmus Lifelong Learning Program (LLP) ${ }^{12}$ Staff Training, contract number YBL: 1/2013-2014. The Aristotle University of Thessaloniki, AUTh was guarantee locality, financial and professional support to the project. Holm Kleinmann (JADE University of Applied Sciences) and Saratntis Zareiropoulos (Aristotle University of Thessaloniki, AUTh) were set out the concept of the introduced MSc course. Thank for them, and for the students, who participated for their creativity. I'm thankful to Belme Dóra for checking the English of the article.

\section{REFERENCES}

[1] KLEINMANN, H., The Thessaloniki Project - Red and Green, Concept of the Project, 2013.

[2] Alieri, M.A., Companioni, N., Cañizares, K., Murphy, C., Rosset, P., Bourque, M., Nicholls, C.I., The greening of the "barrios": Urban agriculture for food security in Cuba, In: Agriculture and Human Values 16, 1999., pp. 131-140

[3] http://www.cityfarmer.info/wp-content/uploads/2008/01/cuba.jpg

[4] Müller, C., Von Stadtpflanzen und Refugien des Selbermachens. Urbane Landwirtschaft als postfossile Strategie. PolitischeÖkologie, Jg. 2011.,H. 124: 67-72.

[5] Toвisch, C., OAsen in Beton, Urban Gardening als Instrument zur Attraktivierung und Belebung von Brachflächen, Diplomarbeit, Dortmund: TechnischeUniversität Dortmund, FakultätRaumplanung, 2013.

[6] http://prinzessinnengarten.net/wir/

[7] Carter, B., Dutch Architecture Firm rethink the Urban Farm, Smart Planet, Issue 18, 2011.

[8] http://c.fastcompany.net/multisite_files/codesign/imagecache/slideshow_large/slides/7-Rice-department.jpg

[9] http://urbanfarmers.com/projects/basel/

[10] http://www.swissworld.org/typo3temp/pics/722ecfa1a6.jpgKLEINMANN, H., The Thessaloniki project - Red and Green, Syllabus and Program of the Project, 2013.

[11] http://en.wikipedia.org/wiki/Via Egnatia

[12] https://www.google.hu/maps/place/Thesszalon\%C3\%ADki/@40.6531301,22.9014699,2248m/ data $=$ !3m1! $1 \mathrm{e} 3 ! 4 \mathrm{~m} 2 ! 3 \mathrm{~m} 1 ! 1 \mathrm{~s} 0 \times 14 \mathrm{a} 838 \mathrm{f} 41428 \mathrm{e} 0 \mathrm{ed}: 0 \times 9 \mathrm{bae} 715 \mathrm{~b} 8 \mathrm{~d} 574 \mathrm{a} 9$

[13] Gavrillidou, E., Dedousi, D., Oureilidou, E., Ritou, M., AgriLaborSchool, Masterplan, 2014

[14] Marmataki, Z., Mastoropoulou, S., Paraschou, A., Piperidou, S.A., LandSCaPE MEDIC (AID), Masterplan, 2014.

[15] http://www.avarositanya.hu/kommunakertek/

[16] Bassiakou,M., Chatzigeorgiou,R., Georgiadou, E., Mavropoulou, A., Agro(Polis), Masterplan, 2014.

[17] Prodromos,V.,Tasos,G., Aphroditi,T., Hatzopoulos,D., Cells, Masterplan, 2014. 